ZOOLOGIA 31 (3): 223-229, June, 2014

http://dx.doi.org/10.1590/S1984-46702014000300003

\title{
Habitat use and movements of Glossophaga soricina and Lonchophylla dekeyseri (Chiroptera: Phyllostomidae) in a Neotropical savannah
}

\author{
Ludmilla M.S. Aguiarr,3, Enrico Bernard² \& Ricardo B. Machado ${ }^{1}$ \\ ${ }^{1}$ Departamento de Zoologia, Instituto de Ciências Biológicas, Universidade de Brasília, Campus Darcy Ribeiro, Asa Norte, \\ 70910-900 Brasília, DF, Brazil. \\ 2 Departamento de Zoologia, Universidade Federal de Pernambuco. Rua Nelson Chaves, Cidade Universitária, \\ 50670-420 Recife, PE, Brazil. \\ ${ }^{3}$ Corresponding author. E-mail: ludmillaaguiar@unb.br
}

\begin{abstract}
The greatest current threat to terrestrial fauna is continuous and severe landscape modification that destroys and degrades animal habitats. This rapid and severe modification has threatened species, local biological communities, and the ecological services that they provide, such as seed dispersal, insect predation, and pollination. Bats are important pollinators of the Cerrado (woodland savanna) because of their role in the life cycles of many plant species. However, there is little information about how these bat species are being affected by habitat loss and fragmentation. We used radio-tracking to estimate the home ranges of Glossophaga soricina (Pallas, 1776) and Lonchophylla dekeyseri Taddei, Vizotto \& Sazima, 1983. The home range of $G$. soricina varies from 430 to 890 ha. They combine shortrange flights of up to $500 \mathrm{~m}$ to nearby areas with longer flights of 2 to $3 \mathrm{~km}$ that take them away from their core areas. The maximum flight distance tracked for L. dekeyseri was $3.8 \mathrm{~km}$, and its home range varies from 564 to 640 ha. The average distance travelled by this species was $1.3 \mathrm{~km}$. Our data suggest that $G$. soricina and L. dekeyseri are able to explore the fragmented landscape of the Central Brazilian Cerrado and that they are likely to survive in the short- to medium-term. The natural dispersal ability of these two species may enable them to compensate for continued human disturbance in the region.
\end{abstract}

KEY WORDS. Bats; Brazil; Cerrado biome; home range; radio-tracking.

Habitat destruction and the associated degradation are the greatest threats to terrestrial fauna. Habitat loss impacts $86 \%$ of threatened mammals (BAilLie et al. 2004), and there is no indication that landscape transformation is diminishing, especially in the Cerrado, which is a Brazilian biome that currently has a high level of industrial agriculture.

The Cerrado of Central Brazil, the most biologically rich savannah in the world, has been under serious threat for the last 35 years. More than $50 \%$ of its land has been lost to pasture and cropland (KLINK \& Machado 2005, BRASIL 2009a). This rapid and severe landscape modification has threatened many species, which in turn has affected local biological communities and the ecological services that they provide, including seed dispersal, insect predation, and pollination. Long-distance pollen dispersal is important for plants, and bat pollinators are particularly well suited to provide this service (FLEMING \& SosA 1994).

Bats are among the most important pollinators of the Cerrado because of their roles in the life cycles of many typical cerrado sensu stricto plant species, such as Caryocar brasiliensis Cambess., Bauhinia holophylla Steud., Hymenaea stigonocarpa Mart and Luehea grandiflora Mart. \& Zucc. (Bobrowiec \& OliveIRA
2012). However, there is little knowledge about how these bat species are being affected by continued habitat loss and fragmentation in the region. There are also a number of gaps in our knowledge of the basic characteristics of the bat species of the Cerrado, including their diet, ecology, roosting requirements, behavior, and physiology (e.g., BERNARD et al. 2011).

Radio-tracking is an important tool in the exploration of how native species perceive the structure of natural or altered landscapes in their habitats. Bats are seemingly unaffected by small changes in landscape structure because of their ability to fly, but contradictory results have been reported in the literature (Fenton 1997, Gorrensen et al. 2005). Part of this contradiction can be explained by the species-dependent nature of responses to landscape change (Gorrensen et al. 2005). AvilaCABADIlla et al. (2012), have shown that nectivorous bats are negatively associated with dry forest patches, while frugivorous bats are positively associated with riparian forest. Phyllostomid bats in savannah areas of the Brazilian Amazon were found by radio-tracking to have ranges of 0.5 to $2.5 \mathrm{~km}$, which demonstrates interspecific differences in flight ability (BERNARD \& FENTON 2003). In contrast, phyllostomids in French Guiana and Panama were reluctant to traverse open spaces that

2014 Sociedade Brasileira de Zoologia | www.sbzoologia.org.br | www.scielo.br/zool All content of the journal, except where identified, is licensed under a Creative Commons attribution-type BY-NC. 
composed a water matrix (Cosson et al. 1999, Albrecht et al. 2007). Therefore, the type of matrix has an impact on flight behavior. The perception of landscape fragmentation may also vary among individuals and species (GorRensen et al. 2005), especially in regions that are naturally composed of a mosaic of different phytophysiognomies (see Montiel et al. 2006, LoAyzA \& Loiselle 2008), such as the Cerrado (woodland savannah) (EITEN 1972).

We do not know how bats are responding to the anthropogenic changes that are occurring in the Cerrado biome. The use of radio-tracking studies may contribute to the understanding of how pollinator bat species are affected. Data on the home range and habitat use of a given species can be applied to determine its dispersal capacity, which indicates the ability of that species to utilize and survive in a fragmented landscape (Lima et al. 2012). This information can be used to establish conservation strategies for bat species, such as defining minimum acceptable distances between roosts and feeding areas, or determining the optimal quality of the ecosystems that they inhabit. We therefore used radio-tracking to investigate habitat use and movements of two small, primarily nectivorous phyllostomid species, Dekeyser's nectar bat - Lonchophylla dekeyseri Taddei, Vizotto \& Sazima, 1983 -, and Pallas' longtongued bat - Glossophaga soricina (Pallas, 1776). The two species are similar in size and diet (both eat pollen, fruits and insects) but differ in abundance. We hypothesize that the home range of the less abundant species (L. dekeyseri) is more restricted than that of $G$. soricina because it avoids crossing altered areas. Thus, we expect that the home range and the mean flight distance of $G$. soricina is greater than that of $L$. dekeyseri.

\section{MATERIAL AND METHODS}

The study was conducted in the Roncador Ecological Reserve (RER - $15^{\circ} 56^{\prime} \mathrm{S}, 47^{\circ} 53^{\prime} \mathrm{W}$ ), which is $35 \mathrm{~km}$ south of the capital Brasília, and near the Sal Fenda cave (SFC - 15³0'35"S, $48^{\circ} 09^{\prime} 59^{\prime \prime} \mathrm{W}$ ) in Brazlândia, which is $45 \mathrm{~km}$ east of Brasília (Fig. 1). Spaced thorny trees ( 3 to $8 \mathrm{~m}$ tall) that are surrounded by smaller bushes and grasslands known as the cerrado sensu stricto characterize the vegetation in both areas. (The cerrado is a phytophysiognomy and Cerrado is the biome). The rainy season lasts from October to April, and the dry season lasts from May to September. The average temperature is $22^{\circ} \mathrm{C}$, and the average annual rainfall is approximately $1,500 \mathrm{~mm}$ (EITEN 1994).

Brazlândia is within the Cafuringa Area of Environmental Protection (APA Cafuringa, 46,000 ha), which contains some of the last remaining native grasslands in the region and several limestone caves in the Distrito Federal itself (BAPTISTA 1998). Sal Fenda is the largest granite cave in the Distrito Federal and is located at $840 \mathrm{~m}$ above sea level. There is an extension of the cave that has an elevation of $865 \mathrm{~m}$. The original cerrado vegetation that surrounded the cave has been heavily deforested and replaced by pastures and degraded semi-deciduous

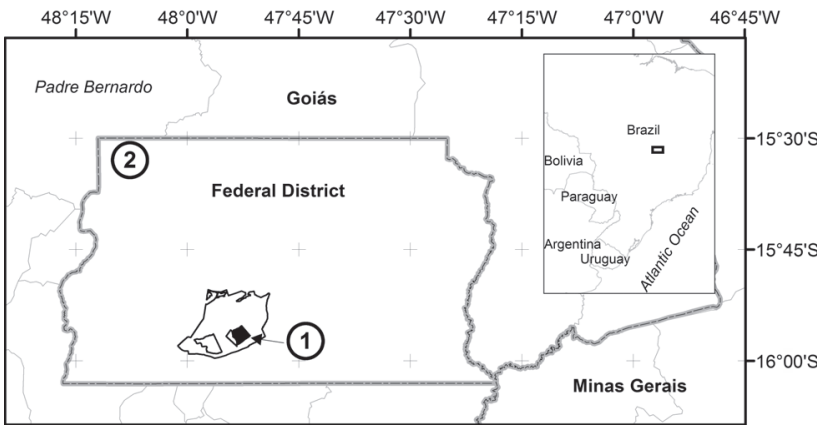

Figure 1. Location of the study sites in the Distrito Federal. The number "1" indicates the Reserva Ecológica do Roncador (RER) within the Área de Proteção Ambiental Gama-Cabeça do Veado, and the number " 2 " indicates the location of the Sal Fenda cave.

forest. The RER is surrounded by two other reserves, the Ecological Station of Brasília's Botanical Garden (JBB) on its northeastern border and Brasília University's Farm Água Limpa (FAL) on its southeastern border. These reserves together form a single large continuous tract of cerrado (sensu stricto). Nearly $75 \%$ of the RER's 1,350 ha are covered by this cerrado, with a heterogeneous landscape that is composed of smooth slopes and is crossed by small rivers and streams.

We defined a polygon of approximately $20 \times 15 \mathrm{~km}$ (approximately 30,000 hectares) around each study site (RER and SFC) to assist in evaluating the status of natural coverage. According to maps prepared in 2009 by the Center for Remote Sensing of the Brazilian Institute of Environment and Renewable Natural Resources (BrasIL 2009b), the remnants of native vegetation cover in the RER area represented $71.2 \%$ of this polygon. There are 15 fragments in the polygon. The average fragment size is of $1163.1 \mathrm{ha}$, and there is an average distance of $138 \mathrm{~m}$ between them. Native remnants represented $52 \%$ of the SEC area. It has 16 fragments, with an average fragment size of 790.4 ha. The average distance between fragments in this area was $395.5 \mathrm{~m}$. We calculated all measurements that presented here with the extension Patch Analyst 5.0 (Rempel et al. 2012) and ArcGIS 10.0 software (ESRI 2010).

Lonchophylla dekeyseri is a small bat $(10.7 \pm 0.85 \mathrm{~g}$; forearm length: $35.3 \pm 8.5 \mathrm{~mm}$ ) that is endemic to the Cerrado. It is threatened by extinction "Endangered" according to the Brazilian Ministry of the Environment and "Near Threatened" according to the IUCN Red List) (BRASIL 2003, IUCN 2011). This species is still relatively unknown and began to receive more attention only after its inclusion in the official list of Brazilian endangered species. In contrast, G. soricina (10.6 $\pm 1.7 \mathrm{~g}$; forearm length: $35.4 \pm 1.4 \mathrm{~mm}$ ) is found from northern México to southern Argentina, including Jamaica and other islands near the northern coast of South America (Alvarez et al. 1991). This widespread species is not at risk of extinction and occupies a large variety of habitats, ranging from arid-subtropical thorn 
forest to tropical rainforests and savannahs, from sea level to 2,600 m elevation (Alvarez et al. 1991). Both species feed on insects, fruits and flower parts in addition to pollen and nectar. The known food sources of these bats include the pollen of several Cerrado plant species, including Hymenaea stigonocarpa Mart, ex Hayne, Bauhinia brevipes Vogel, Bauhinia cupulata Benth., Bauhinia multinervia (Kunth) D.C., Bauhinia megalandra Griseb., Bauhinia pauletia Pers., Bauhinia ungulata L., Bauhinia rufa (Bong.), and Luehea speciosa Wild. (GibBs et al. 1999, GribeL \& Hay 1993, Heithaus et al. 1975, Hоксhe \& Ramírez 1990, Ramírez et al. 1984).

From 6-9 September 2005, four G. soricina individuals (one male, three females) were captured at RER, and from 1012 October 2005, 10 L. dekeyseri individuals (five males, five females) were captured at the entrance of the Sal Fenda cave. All of the bats were captured with mist nets that were set around flowering pequi trees (C. brasiliensis). Radio transmitters (model LB-2, Holohil, Carp, Ontario, Canada) that were compliant with the 5\% mass limit rule (ALDRIDGE \& BRIGHAM 1988) were glued to the backs of the bats with Skin-Bond glue. Three pairs of researchers who were in radio contact with each other tracked the bats. At RER, where only G. soricina was tracked, two of the tracking teams were stationed at the tops of two existing 8and $12-\mathrm{m}$ towers, while the third team was instructed to move around to improve signal reception (White \& GaRRotT 1990, Mason \& Hope 2014). At Sal Fenda, where only L. dekeyseri was tracked, two 6-m aluminum pole structures were constructed to hold one antenna each, and the third was mobile (WHite \& Garrott 1990, Mason \& Hope 2014).

The location of each tracking station was marked using the average function of a GPS device (Garmin ETrex). The receivers that were used were TRX-1000 models (Wildlife Materials, Murphysboro, Illinois, USA) paired with Yagi Three-Element Antennas (Titley Scientific, Columbia, Missouri, USA). The teams attempted to locate each bat and collect a location point for each individual at five-minute intervals over the tracking period. Three bearings (one per team) were required for a location to be recorded (White \& GARRotT 1990). A bat was considered stationary when three consecutive bearing measurements indicated the same position for an individual. Data on the frequencies, date, time, and direction of the strongest signal intensities were taken as positional bearings using a compass and were recorded for each bat (White \& Garrott 1990, Mason \& Hope 2014).

The trajectory of displacement for each of the bats was represented by the sum of the sequential movements of each individual. A movement corresponded to the distance that was covered between two points as measured by triangulation of the bearings (White \& Garrott 1990, Mason \& Hope 2014). It was therefore possible to obtain the pattern of dispersion for each bat at the end of a tracking session.

The average distance covered and the flight directions taken by all of the tracked bats were recorded and plotted on a map. The bats were tracked until their signals were lost. $G$. soricina individuals were tracked from approximately 18:00 to 03:00 $\mathrm{h}$ the following day, and L. dekeyseri individuals were tracked from approximately 18:00 to 05:00 h.

The home range for each individual was calculated using the 'Animal Movement' extension (Hooge et al. 2001) of the ArcView 3.3 software (ESRI 2002) and was based on minimum convex polygons (MCP) and 95\% kernel estimators (Hooge \& Eichenlaub 1997, Jacob \& Rudran 2003, White \& GARROTT 1990). To estimate the type and prevalence of the habitats that were within the calculated home ranges, the polygons were plotted on a 30-m resolution, classified Landsat ETM+ satellite image (taken on August 2002) that contained three native vegetation classes (cerrado, grassland, and forest) and one altered class (grouped anthropogenic areas, such as pasture, crop, urban and deforested areas).

\section{RESULTS}

Two of the four tracked G. soricina individuals (one male and one female) disappeared immediately following their release, and their signals were not detected for the remainder of the study. The two remaining individuals (females \#58 and \#69) were tracked for seven consecutive days, resulting in 105 location records (Table I). Based on their MCPs, their home ranges varied from 427 to 893.6 ha (Fig. 2). Both of the tracked individuals combined short-range flights of up to $500 \mathrm{~m}$, possibly to scan nearby areas, with longer distance flights of 2 to $3 \mathrm{~km}$ to reach areas that were more distant from the core. The two bats used different parts of their home ranges to different degrees. On average, the main habitat types that they visited were cerrado vegetation (49.7\%), grasslands (6\%), and gallery forest areas (14.0\%, used just twice) (Table II). The bats crossed disturbed areas (pasture and crops) to reach native areas that were outside of the RER. Based on 27 movements, the maximum flight distance tracked was $3.8 \mathrm{~km}$ and the average distance was $1.5 \mathrm{~km}(\mathrm{SD}=0.9 \mathrm{~km})$.

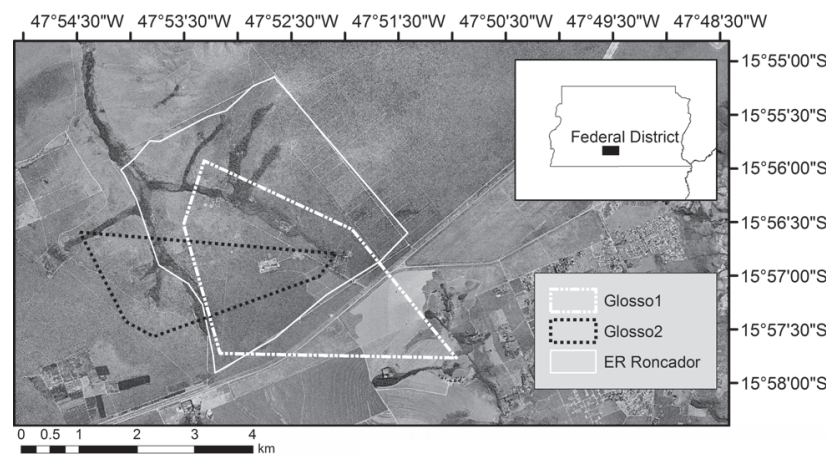

Figure 2. Home ranges of the two radio-tracked Glossophaga soricina bats (white polygons) in the Reserva Ecológica do Roncador (RER) (black polygon). 
Table I. Basic data from each transmitter used to evaluate home range and movements of Glossophaga soricina and Lonchophylla dekeyseri in the Cerrado of Brasília, Brazil.

\begin{tabular}{lllrrr}
\hline \multicolumn{1}{c}{ Species } & Indiv. & \multicolumn{1}{c}{ Date } & $\begin{array}{r}\text { Time } \\
(\mathrm{min})\end{array}$ & Valid points & Frequency \\
\hline Glossophaga soricina & $\# 58$ & 6-8/Sep & 580 & 85 & 151.140 \\
Clossophaga soricina & $\# 69$ & 9/Sep & 100 & 20 & 151.155 \\
Lonchophylla dekeyseri & $\# 59$ & 10-Oct & 600 & 15 & 151.161 \\
Lonchophylla dekeyseri & $\# 60$ & $10-12 /$ Oct & 1800 & 35 & 151.180 \\
Lonchophylla dekeyseri & $\# 61$ & $10-12 /$ Oct & 1800 & 15 & 151.198 \\
Lonchophylla dekeyseri & $\# 62$ & 10-Oct & 600 & 4 & 151.220 \\
\hline
\end{tabular}

${ }^{1}$ The Time column indicates the total time that the individual was tracked in the study region.

${ }^{2}$ The Valid points column indicates the number of triangulated points that were used to calculate the individual's home range.

Table II. Composition of the native and anthropogenic environments within the home range of the tracked individuals of Glossophaga soricina at RER, Brasilia, Brazil.

\begin{tabular}{|c|c|c|c|c|c|c|}
\hline \multirow{2}{*}{ Coverage } & \multicolumn{2}{|c|}{ Indv. 58} & \multicolumn{2}{|c|}{ Indiv. 62} & \multicolumn{2}{|c|}{ Mean } \\
\hline & Area (ha) & $\%$ & Area (ha) & $\%$ & Area (ha) & $\%$ \\
\hline Pasture/grass & 17.30 & 4.1 & 152.6 & 17.1 & 161.3 & 14.6 \\
\hline Forest & 72.90 & 17.1 & 118.9 & 13.3 & 155.3 & 14.0 \\
\hline Cerrado s.s. & 214.50 & 50.2 & 443.3 & 49.6 & 550.5 & 49.7 \\
\hline Grassland & 14.20 & 3.3 & 58.8 & 6.5 & 65.9 & 6.0 \\
\hline Others (nonnative) & 108.09 & 25.3 & 120.0 & 13.4 & 174.0 & 15.7 \\
\hline Total & 427.00 & & 893.6 & & 660.3 & \\
\hline
\end{tabular}

Six of the 10 L. dekeyseri individuals that were equipped with transmitters disappeared immediately after release and their signals were not recorded for the remainder of the tracking period. Two of the four remaining bats (females \#60 and \#61) were tracked for three consecutive nights, while the others (females \#59 and \#62) were tracked for a single night before their signals disappeared. The tracking of these four bats resulted in 69 location records (Table I). Three of the four tracked bats provided enough readings to estimate their home ranges (Fig. 3). Their average home range was 640 ha (SD $=704$ ha) based on the MCPs and 564 ha (SD = 265 ha) based on 95\% kernel estimates. The bats explored both fragments and forests, with an average of $53 \%$ of their home ranges (approximately 343 ha) being composed of cerrado and the remaining $47 \%$ of pasture (Table III).

In general, these home ranges were composed of irregular terrain, with drier forests along the steepest parts of the area and rock outcrops. Most of the native areas were in poor conservation condition, and there were cattle in several areas. Consequently, the understory in those areas was more degraded and more open than expected. Like the G. soricina individuals, the tracked $L$. dekeyseri individuals visited different parts of their home ranges during different nights. For example, one female
(\#60) visited the northeastern, northwestern, and northern parts of its home range and several points along the southern, southwestern and northeastern areas on four consecutive nights. The average movement distance of this species was 1.3 $\mathrm{km}(\mathrm{SD}=1.0 \mathrm{~km})$, and the greatest distance flown was $3.8 \mathrm{~km}$. The tracked bats exhibited two activity peaks, at approximately 19:00 and 02:00 h. The lowest activity occurred at approximately 21:00 and 04:00 h.

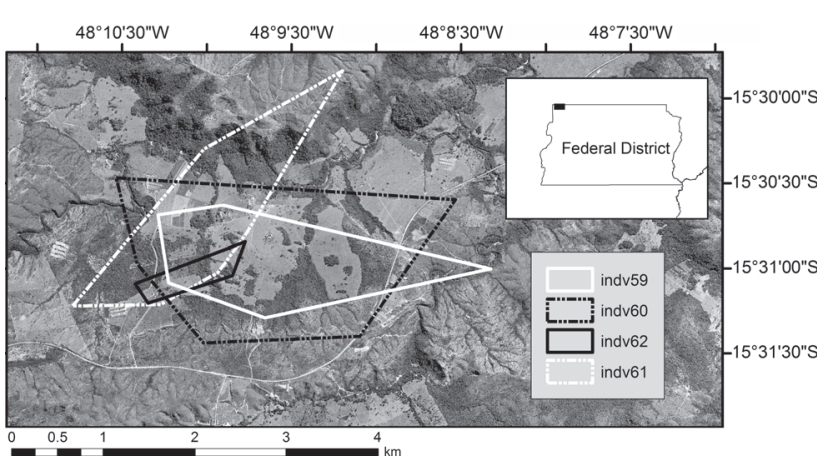

Figure 3. Home ranges of the four radio-tracked Lonchophylla dekeyseri bats in the northern region of the Distrito Federal.

Table III. Composition of the native and anthropogenic environments within the home range of the tracked individuals of Lonchophylla dekeyseri at Sal Fenda Cave, Brazlândia, Brazil.

\begin{tabular}{|c|c|c|c|c|c|c|c|c|}
\hline \multirow[b]{2}{*}{ Coverage } & \multicolumn{2}{|c|}{ Indiv. 59} & \multicolumn{2}{|c|}{ Indiv. 60} & \multicolumn{2}{|c|}{ Indiv. 61} & \multicolumn{2}{|c|}{ Mean } \\
\hline & $\begin{array}{l}\text { Area } \\
\text { (ha) }\end{array}$ & $\%$ & $\begin{array}{l}\text { Area } \\
\text { (ha) }\end{array}$ & $\%$ & $\begin{array}{l}\text { Area } \\
\text { (ha) }\end{array}$ & $\%$ & $\begin{array}{l}\text { Area } \\
\text { (ha) }\end{array}$ & $\%$ \\
\hline Pasture & 105.8 & 44.7 & 700.2 & 48.2 & 73.7 & 32.0 & 293.2 & 45.8 \\
\hline Forest & 93.1 & 39.3 & 274.3 & 18.9 & 99.5 & 43.2 & 155.6 & 24.3 \\
\hline Cerrado s.s. & 24.0 & 10.2 & 335.8 & 23.1 & 30.9 & 13.4 & 130.3 & 20.3 \\
\hline Grassland & 13.7 & 5.8 & 143.6 & 9.9 & 16.8 & 7.3 & 58.0 & 9.1 \\
\hline $\begin{array}{l}\text { Others } \\
\text { (nonnative) }\end{array}$ & 0.0 & 0.0 & 0.0 & 0.0 & 9.3 & 4.0 & 3.1 & 0.5 \\
\hline Total & 236.6 & & 1453.9 & & 230.2 & & 640.3 & \\
\hline
\end{tabular}

\section{DISCUSSION}

Although the sample sizes in the present study are small and the measurements were limited to the dry season, the data support the hypothesis that the home range of $G$. soricina is larger than that of $L$. dekeyseri. The sample sizes do not permit more powerful statistical comparisons. The flight distances that were recorded for both species were similar. We therefore cannot confirm our hypothesis regarding differences in flight distance. Both species showed the same ability to visit natural vegetation patches in the study areas.

The characteristics of the vegetation structure of the study areas did not impose any significant impediment to radio signal transmission. This allowed us to detect signals at distances 
of up to $5 \mathrm{~km}$. This detection distance was even greater when the antennas were positioned on a 10- to 12-meter-high fire observation tower. Other studies (MCGUIRE 2010) have reported detection of signals from bats that were equipped with such small radios at distances of up to $12 \mathrm{~km}$ in estuarine regions.

RothENWÖHRER et al. (2011) state that the spatial and temporal activity of Glossophaga commissarisi Gardner, 1962 are closely matched to the local resource landscape, with high resource density allowing smaller home ranges, lower flight duration and thus reduced foraging costs. G. soricina and L. dekeyseri were much more mobile than expected despite their small body sizes. Both species are able to consume pollen, fruits and insects, suggesting that their broad home ranges reflect the wide spatial distribution of food or food quality rather than food scarcity. Previously published data show that bats of the savannahs of Brazil, Bolivia and Africa have smaller home ranges and flight distances than those that were observed in the present study. For example, the home range of G. commissarisi, at La Selva (Costa Rica) ranges from 7.4 to 23.9 ha (RotHENWÖHRER et al. 2011), and that of Artibeus watsoni Thomas, 1901 is 3.6 ha (RotHENwÖHRER et al. 2011). Carollia perspicillata (Linnaeus, 1758), a larger but still small frugivore, was found to have a home range of 155 to 320 ha in the savannah of the Brazilian Amazon (Bernard \& FENTON 2003). Even when we compare data that were collected only from areas of open vegetation, the home ranges of our study exceed those that have been reported for larger species. In the Bolivian savannah, the home range of Sturnira lilium (E. Geoffroy, 1810) ranges from 36.5 to 190.7 ha (LOAYZA \& LOISELLE 2008), and the home range of Megaloglossus woermannii Pagenstecher, 1885, (which weighs less than $20 \mathrm{~g}$ ) in the Lama Forest Reserve, southern Benin, West Africa, varies from 99.8 to 146.8 ha (Weber et al. 2009).

The larger home ranges that were observed in the present study for both $L$. dekeyseri and G. soricina might be explained by one of two different hypotheses. First, the ability to fly longer distances than those observed in other regions may be a consequence of the natural horizontal heterogeneity of the Cerrado. The Cerrado is a mosaic of different vegetation physiognomies, from grassland to forest, and it varies on the horizontal scale at the level of hundreds of meters (EITEN 1972, 1994). This characteristic of the Cerrado may encourage environmental plasticity of its bat species through the separation of habitat types. In this case, covering distances of 1 to $3 \mathrm{~km}$ to explore the surrounding area would be a natural circumstance for these animals, and may be sufficient to allow them to survive in landscapes with an intermediate level of fragmentation (such as the study site, where the fragments are separated by an average distance of 300-400 $\mathrm{m}$ ).

Alternatively, these longer flight distances may be a result of the habitat fragmentation of the study areas. The bats may have to fly long distances to find suitable habitat fragments. The longer flight distances of both species are noteworthy regardless of the underlying cause.
Others have argued that the nectar-feeding phyllostomid bats of the subfamilies Lonchophyllinae and Glossophaginae are highly susceptible to extinction because many of these species are food and habitat specialists, roost in caves, show migratory behavior, and are already rare (ARITA \& SANTOS-DEL-PRADO 1999). Others have found that these species are more resilient than other guilds to changes in land use (Willig et al. 2007). Our data indicate that G. soricina and L. dekeyseri are able to utilize the fragmented landscape of the Central Brazilian cerrado successfully. This ability may make them more likely to survive in the short run, but we still do not know how the quality of these different remnant fragments influences the long-term survival of both species. Nevertheless, populations of $L$. dekeyseri are declining in response to habitat loss and human disturbance (Aguiar et al. 2010), and this species has already been declared as endangered (BrasiL 2003).

\section{ACKNOWLEDGEMENTS}

This study is part of the L. dekeyseri Action Plan. We thank PROBIO/FNMA/CNPq for funding this research. We thank field assistants Adriana Bochiglieri, Nicholas Camargo, William Camargo, Alexandre Portela, and Fábio Souza for their invaluable help in the fieldwork. We also thank Brock Fenton and three other anonymous reviewers for their invaluable comments. CNPq provides a research fellowship to RBM. English revision was done by American Jounal Expert Reviews (AJE).

\section{LITERATURE CITED}

Aguiar, L.M.S.; D. Brito \& R.B. Machado. 2010. Do current vampire bat (Desmodus rotundus) population control practices pose a threat to Dekeyser's nectar bat's (Lonchophylla dekeyseri) long-term persistence in the Cerrado? Acta Chiropterologica 12 (2): 275-282. doi: 10.3161/150811010X537855

Albrecht, L.; C.F.J. Meyer \& E.K.V. Kalko. 2007. Differential mobility in two small phyllostomid bats, Artibeus watsoni and Micronycteris microtis, in a fragmented Neotropical landscape. Acta Theriologica 52 (2): 141-149.

Aldridge, H.D.J.N. \& R.M. Brigham. 1988. Load carrying and manoeuvrability in an insectivorous bat: a test of the 5\% rule of radio-telemetry. Journal of Mammalogy 69 (2): 379382.

Alvarez, J.; M.R. Willig; J.K.J. Jones \& W.D. Webster. 1991. Glossophaga soricina. Mammalian Species 379: 1-7.

Arita, H.T. \& K. Santos-del-Prado. 1999. Conservation biology of nectar-feeding bats in Mexico Journal of Mammalogy 80 (1): 31-41.

Avila-Cabadilla, L.D.; G.A. Sanchez-Azofeifa; K.E. Stoner; M.Y. Alvarez-Añorve; M. Quesada \& C.A. Portillo-Quintero. 2012. Local and landscape factors determining occurrence of Phyllostomid bats in tropical secondary forests. PLoS ONE 7: e35228. doi:10.1371/journal.pone.0035228 
Baillie, J.E.M.; L.A. Bennun; T.M. Brooks; S.H.M. Butchart; J.S. Chanson; Z. Cokeliss; C. Hilton-Taylor; M. Hoffmann; G. Mace $\&$ S.A. MAINKA. 2004. IUCN Red List of Threatened Species - a global species assessment. Cambridge, The IUCN Species Survival Commission.

BAPTISTA, G.M.M. 1998. Caracterização climatológica do Distrito Federal, p. 187-208. In: Inventário hidrogeológico e dos recursos hídricos superficiais do Distrito Federal. Brasília, IEMA/SEMATEC/UnB.

Bernard, E. \& M.B. Fenton. 2003. Bat mobility and roosts in a fragmented landscape in central Amazonia, Brazil. Biotropica 35 (2): 262-277. doi: 10.1111/j.1744-7429.2003.tb00285.x

Bernard, E.; L.M.S. Aguiar \& R.B. Machado. 2011. Discovering the Brazilian bat fauna: a task for two centuries? Mammal Review 41 (1): 23-39. doi: 10.1111/j.1365-2907.2010.00164.x

Bobrowiec, P.E.D. \& P.E. Oliveira. 2012. Removal effects on nectar production in bat-pollinated flowers of the Brazilian Cerrado. Biotropica 44 (1): 1-5. doi: 10.1111/j.1744-7429.2011.00823.x

BRASIL. 2003. Espécies da fauna brasileira ameaçadas de extinção, p. 88-97. In: Instruction 3 of 27 May 2003. Brasília Ministério do Meio Ambiente, Published in the Official Gazette 101 of 28 May 2003, Section 1.

BRASIL. 2009a. Technical Report on monitoring deforestation in the Cerrado biome, 2002 a 2008 revised data. Brasília, MMA/IBAMA/CID.

BRASIL. 2009b. Mapas de cobertura vegetal dos biomas brasileiros. Brasília, Secretaria de Biodiversidade e Florestas, Ministério do Meio Ambiente-MMA.

Cosson, J.F.; S. Ringuet; O. Claessens; J.C. de Massary; A. Dalecky; J.F. Villiers; L. Granjon \& J.M. Pons. 1999. Ecological changes in recent land-bridge islands in French Guiana, with emphasis on vertebrate communities. Biological Conservation 91 (23): 213-222. doi: 10.1016/S0006-3207(99)00091-9

Erten, G. 1972. The Cerrado vegetation of Brazil. Botanical Review 38 (2): 201-341.

Eiten, G. 1994. CerradoVegetation. In: M. Pinto (Ed.). Cerrado: characterization, occupation and perspectives. Brasília, Editora Universidade de Brasília.

EsRI. 2002. ArcView 3.3 - Geographical information system. Readlands, Environment System Research Institute, Inc.

ESRI. 2010. ArcGIS 10.0 - Geographical Information System. Readlands, Environment System Research Institute, Inc.

Fenton, M.B. 1997. Science and the conservation of bats. Journal of Mammalogy 78 (1): 1-1.

FLEMING, T.H. \& V. Sosa. 1994. Effects of nectarivorous and frugivorous mammals on reproductive success of plants. Journal of Mammalogy 75 (4): 845-851.

Gibis, P.E.; P.E. Oliveira \& M.B. Bianchi. 1999. Postzygotic control selfing in Hymenaea stigonocarpa (Leguminosae-Caesalpinioideae), a bat-pollinated tree of the Brazilian cerrados. International Journal of Plant Science 160 (1): 72-78.

Gorrensen, P.M.; M.R. Willig \& R.E. Strauss. 2005. Multivariate analysis of scale-dependent associations between bats and landscape structure. Ecological Applications 15 (6): 21262136. doi: 10.1890/04-0532

Gribel, R. \& J. D. Hay. 1993. Pollination ecology of Caryocar brasiliensis (Caryocaraceae) in Central Brazil cerrado vegetation. Journal of Tropical Ecology 9 (2): 199-211. doi: 10.1017/S0266467400007173

Heithaus, E.R.; T.H. Fleming \& P.A. Opler. 1975. Foraging patterns and resource utilization in seven species of bats in a seasonal tropical forest. Ecology 56 (4): 841-854.

Ноксне, O. \& N. Ramírez. 1990. Pollination ecology of seven species of Bauhinia L. (Leguminosae: Caesalpinioideae). Annals of Missouri Botanical Garden 77 (3): 559-572.

Hooge, P.N. \& W. Eichenlaub. 1997. Animal movement extension to arcview ver. 1.1. Anchorage, Alaska Biological Science Center, U.S. Geological Survey.

Hooge, P.N.; W. Eichenlaub \& E.R. Hooge. 2001. Animal movement 2.5. Anchorage, US geological survey, Alaska Biological Science Center.

IUCN. 2011. Iucn Red List of Threatened Species. Version 2011.1.

JACOB, A.A. \& R. RudRAn. 2003. Radiotelemetry in population studies, p. 285-342. In: L.C. Cullen JR; R. Rudran \& C. Valladares-PÁdua (Eds). Study methods in conservation biology and wildlife management. Curitiba, Paraná.

KuINK, C.A. \& R.B. Machado. 2005. Conservation of the Brazilian Cerrado. Conservation Biology 19 (3): 707-713. doi: 10.1111/ j.1523-1739.2005.00702.x

Lima, E.S.; K.E. Dematteo; R.S.P. Jorge; M.L.S.P. Jorge; J.C. DalPonTE; H.S. LIMA \& S.A. KLORINE. 2012. First telemetry study of bush dogs: home range, activity and habitat selection. Wildlife Research 39 (6): 512-519. doi: 10.1071/ WR11176

Loayza, A. \& B. A. Loiselle. 2008. Composition and distribution of a bat assemblage during the dry season in a naturally fragmented landscape in Bolivia. Journal of Mammalogy 90 (3): 732-742. doi: 10.1644/08-MAMM-A-213R.1

McGuire, L. P. 2010. Bat Migration Stopover Ecology. Ontario, Ontario Ministry of Natural Resources, Technical Report.

Mason, V. \& P.R. Hope. 2014. Echoes in the dark: Technological encounters with bats. Journal of Rural Studies 33: 107118. doi: 10.1016/j.jrurstud.2013.03.001

Montiel, S.; A. Estrada \& P. León. 2006. Bat assemblages in a naturally fragmented ecosystem in the Yucatan Peninsula, Mexico: species richness, diversity and spatio-temporal dynamics. Journal of Tropical Ecology 22: 267-276. doi: 10.1017/S026646740500307X

Ramírez, N.; C. Sobrevila; N.X. Enrech \& T. Ruiz-Zapata. 1984. Floral biology and breeding system of Bauhinia benthamiana Taub. (Leguminosae), a bat-pollinated tree in Venezuelan Llanos. American Journal of Botany 71 (2): 273-280.

Rempel, R.S.; D. Kaukinen \& A.P. Carr. 2012. Patch Analyst and Patch Grid. Ontario, Ontario Ministry of Natural Resources, Centre for Northern Forest Ecosystem Research. 
RothenwÖHrer, C.; N.I. Becker \& M. Tschapka. 2011. Resource landscape and spatio-temporal activity patterns of a plantvisiting bat in a Costa Rican lowland rainforest. Journal of Zoology 283 (2): 108-116. doi: 10.1111/j.1469-7998.2010. 00748.x

White, G.C. \& R.A. Garrott. 1990. Analysis of wildlife radiotracking data. San Diego, Academic Press.

Willig, M.R.; S.J. Presley; C.P. Bloch; C.L. Hice; S.P. Yanoviak; M.M. Diaz; L.A. Chauca; V. Pacheco \& S.C. Weaver. 2007.
Phyllostomid bats of lowland Amazonia: effects of habitat alteration on abundance. Biotropica 39 (6): 737-746. doi: 10.1111/j.1744-7429.2007.00322.x

Weber, N.; E.K.V. Kalko \& J. Fahr. 2009. A First Assessment of Home Range and Foraging Behaviour of the African LongTongued Bat Megaloglossus woermanni (Chiroptera: Pteropodidae) in a Heterogeneous Landscape within the Lama Forest Reserve, Benin. Acta Chiropterologica 11 (2): 317-329. doi: 10.3161/150811009X485558

Submitted: 28.IX.2013; Accepted: 06.IV.2014.

Editorial responsibility: Diego Astúa de Moraes 